\title{
Trust and boundary spanners in cross-border management
}

Authors

Michael Wei Zhang, Nottingham Trent U., michael.zhang@ntu.ac.uk

Paul Gooderham, Norwegian School of Economics, paul.gooderham@nhh.no 


\title{
TRUST AND BOUNDARY SPANNERS IN CROSS-BORDER MANAGEMENT
}

\begin{abstract}
Boundary spanners play a critical yet unspecified role in managing multinational corporations and their foreign subunits. One of the boundary spanning functions is to build cross-border trust relationships, at both interpersonal and interorganizational levels. Previous research has primarily focused on dyadic exchange relationships either between MNC headquarters and their subunits or between suppliers and buyers. Inter-unit trust relationships and boundary spanning activities in international joint ventures (IJVs) are under-researched. We develop a micro-macro process model of trust building and boundary spanning, and propose a set of propositions for future research.
\end{abstract}

Keywords: inter-unit boundary spanning, interpersonal trust, inter-unit trust, inter-organizational trust, intra-organization conflict management, micro-macro linkage 


\section{INTRODUCTION}

The duel-process of international expansion of multinational corporations (MNCs), through globalization (Dunning, 2003, 2007; Yip, 1992) and regionalization (Ghemaway, 2005; Rugman \& Verbeke, 2004, 2007), has helped MNCs to globally increase their economies of scale and improve the capabilities of innovation and learning (Doz, 1996; Parkhe, 1991; Tallman \& Chacar, 2011). At the same time, by creating cross-border strategic alliances in various forms including foreign subsidiaries and international joint ventures (IJVs), MNCs have become structurally more complex and geographically more dispersed. As a result, MNCs face the challenges of discerning blurred organizational boundaries, reconfiguring the existing control mechanisms, integrating diversified resources, and coordinating distributed subunit activities in time and space (Brouthers \& Hennart, 2007; Choi \& Beamish, 2004; Kostova \& Roth, 2003; Krishnan, Martin \& Noorderhaven, 2006; Parkhe, 1991). Global strategic alliances in general and IJVs in particular, face divergent underlying strategic motives amongst the partners. From MNC headquarters' perspective, ensuring that subunits' activities and performance are aligned with their own goals and objectives is critical yet problematic (Chen, Paik \& Park, 2010; Chen, Park \& Newburry, 2009; Fryxell, Dooley \& Vryza, 2002; Parkhe, 1991). To align the partners' goals and performance targets satisfactory cooperation between the partners is required (Doz, 1996; Das \& Teng, 1998). Theoretically, IJVs involving partners from developed economies and emerging markets possess potential structural and resource complementarity where MNCs contribute technology and international marketing skills while local partners provide labour and local market knowledge (Fryxell et al., 2002; Hitt, Dacin, Levitas, Arregle \& Borza, 2000; Inkpen \& Beamish, 1999). With advanced and sophisticated control mechanisms in place, IJVs are expected to achieve targeted synergistic performance and competitive advantage. Some studies have focused primarily on the 
relationship between control mechanisms and IJV performances (Choi \& Beamish, 2004; Chen et al., 2009).

However, research on the control-performance relationship offers inconsistent and equivocal findings (Fryxell et al., 2002; Robson, Leonidou \& Katsikeas, 2002). Empirically the success rate of IJVs has been estimated to be less than 50 percent (Bamford, Ernst \& Gubini, 2004; Geringer \& Hebert, 1991). Fryxell, Dooley and Vryza (2002) contend that the assumption that there is a positive correlation between control and performance is questionable. Some scholars started to investigate the effects of contingent variables of which one is trust (Das \& Teng, 1998; Fryxell et al., 2002). Whilst Das and Teng (1998) delineate trust and control as parallel processes determining MNC performance, Fryxell, Dooley and Vryza (2002) identified IJV age and affect-based trust as two contingent variables moderating MNC performance. Other scholars go even further by arguing that trust between MNC partners is a key construct of research (Robson, Katsikeas \& Bello, 2008; Zaheer, McEvily \& Perrone, 1998).

The concept of trust is originally rooted in psychology and social psychology. Trust is multifaceted and multi-level in its definition and application (Rousseau, Sitkin, Burt \& Camerer, 1998). It is augured and found that trust can reduce transaction costs and the level of risk, discourage opportunistic behavior, and improve partner cooperation (Das \& Teng, 1998; Williamson, 1993; Zaheer et al., 1998). We note that when international business researchers examine the effect of trust on cross-border cooperation and MNC performance, they have paid particular attention to the role of boundary spanners and boundary spanning activities at various organizational levels (Barner-Rasmussen, Ehrnrooth, Koveshnikov \& Mäkelä, 2014; Koveshnikov, Barner-Rasmussen, 
Ehrnrooth \& Mäkelä, 2012; Kostova \& Roth, 2003; Mudambi \& Swift, 2009; Perrone, Zaheer \& McEvily, 2003; Schotter \& Beamish, 2011; Zaheer et al., 1998). The reason for the introduction of the concept of boundary spanners in this stream of literature is twofold: one is structural and the other is trust-related. First, simultaneously operating in multiple overseas markets with institutional and cultural differences, MNCs face more challenges than their domestic counterparts in managing and monitoring performance. With blurred boundaries and increased structural complexity within the MNC conflicts can occur more frequently (Schotter \& Beamish, 2011). Conflicts can be viewed as either functional or affective (Amason, 1996; Amason \& Schweiger, 1994). When a conflict is oriented at tasks and focused on judgmental differences about how best to achieve common objectives it is called cognitive conflict. In contrast, when a conflict involves emotion and is focused on personal incompatibilities or disputes it is called affective conflict (Amason \& Schweiger, 1994). We argue that the importance of and demand for boundary spanning activities grows to resolve this kind of affective partner conflicts in IJVs in order to improve performance and outcomes.

Second, trust relationships between and amongst partners within the MNC need building and nurturing. Building and nurturing trust is fundamentally a social process (Kostova \& Roth, 2003; Madhok; 1995) that requires boundary spanners from respective partners to manage because they have more opportunities than others to interact with each other (Friedman \& Podolny, 1992; Zaheer et al., 1998). In previous research boundary spanning is studied mainly by strategy and organization researchers. Despite the lack of clear definition of boundary spanning, the concept has been applied in research at multiple levels including inter-personal, inter-group, inter-unit and organization-environment boundaries (Aldrich \& Herker, 1977; Ancona \& Caldwell, 1992; 
Friedman \& Podolny, 1992; Tushman.\& Scanlan, 1981). International business scholars adopted the concept in their research on trust relationships in MNCs without explicating the meaning of boundary spanning. It is compelling that we need to clarify the concept especially when the context of our research is significantly more diversified in terms of cultural and institutional differences (Currall \& Inkpen, 2002; Zaheer et al., 1998).

In the backdrop of growing interest in trust and boundary spanning shown by international business scholars and more frequent appearance of research papers in international business related journals in the last decade or so, it seems to be timely that we should take the stock of current research and theoretically further develop these two concepts for a better understanding and application of the key concepts and its related constructs in future research. In this paper we aim to achieve two research objectives. First, we will explicate the meaning of boundary spanning and trust by examining the antecedents and evolution of the concepts. Second, we advance current analytical models which link the micro-level managerial boundary spanning and trust building with macrolevel organizational boundary spanning and trust building. We contribute to the literature by focusing on inter-unit boundary spanning and trust building in international joint ventures which are under-researched. We develop a micro-macro process model of boundary spanning and trust building and propose a set of propositions for empirical research in the near future.

\section{BOUNDARY SPANNING IN MNCS}

\section{Organizational boundaries}

Aldrich \& Herker (1977) argue that boundaries are a defining characteristic of organizational structure. Analysis of macro factors influencing organizational strategy and behaviour can only be 
carried out if and when the location of the boundary between the organization and its business environment is defined. In a similar vein, group and unit boundaries can also exist within organizations (Ancona \& Caldwell, 1992; Friedman \& Podolny, 1992; Mudambi \& Swift, 2009), or communication boundaries between an organization's subunits and their external information sources (Tushman, 1977; Tushman.\& Scanlan, 1981). In the past, MNCs, in a manner akin to their domestic counterparts, organised their cross-border activities through headquarters' hierarchical control of their subunits and subsidiaries with well-defined boundaries (Bartlett \& Ghoshal, 1989). Recent research evidence shows that MNCs have increasingly become a networked organization with less hierarchical relationships between the parent headquarters and the subunits (Forsgren,

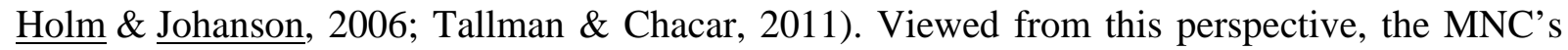
organizational structure is more complex with blurred boundaries both internally and externally. Brouthers and Hennart (2007) argue that due to conflicting findings from previous research a host of questions regarding MNC organizational boundaries when they expand abroad remain open. Yet, they point out that this is a critical issue for MNC managers to consider when making decisions of foreign market entry choice and cross-border operation. Robson, Katsikeas and Bello (2008) contend that the research on MNC boundary conditions for examining performance in relation to trust is scant due to inter-partnership complexity. Therefore, it is critical that we define the organizational boundaries of MNC upon which we identify boundary spanners who are engaged in boundary spanning activities.

\section{Boundary spanners}

There is little evidence that a clear conceptual definition of boundary spanner exists. Scholars define the concept in an ad hoc manner. Ancona and Caldwell (1992) focus on boundary spanning 
activities and their effect on organizational performance. They implied that team members engaged in boundary spanning activities are boundary spanners. Friedman and Podolny (1992: 29, italic added) define boundary spanners as ‘individuals who are responsible for contacting people outside their own groups'. Kostova and Roth (2003: 304, italic added) define a boundary spanner 'as an individual employed at a subunit who currently has, or has previously had, direct contact(s) with a headquarters representative (or representatives)'. Barner-Rasmussen, Ehrnrooth, Koveshnikov and Mäkelä (2014: 887, italic added) define boundary spanners as ‘individuals who are perceived by other members of both their own in-group and/or relevant out-groups to engage in and facilitate significant interactions between the two groups'. We echo Schotter and Beamish's (2011: 255) note in their recent research that there is not 'a formal position or a job description that would specifically include the boundary spanning responsibility'. This can be better captured when we look into the difference between a job and a role in the organization as Perrone, Zaheer and McEvily (2003: 424, italic added) note 'while a job (i.e., the set of task elements assigned to a single employee) is the component of an individual's work experience that is relatively fixed, formal, and derived from the structural properties of an organization, a role is the more emergent, dynamic, and socially defined component of the very same experience.'

Friedman and Podolny (1992: 45) also argue that in research we need to consider boundary spanners "not as nominal positions that are given but, rather, as potential concrete social relations that must be identified empirically.” It is understood that boundary spanners are task oriented primarily for building relationship through communication and interaction. Therefore, to better understand boundary spanners one needs to look at the roles and functions of boundary spanners. 


\section{Boundary spanning roles and functions}

Boundary spanning functions and the roles of those who engaged in those functions, boundary spanners, have been the focus of research since the 1970s. Aldrich and Herker (1977) identified two types of boundary spanning functions: information processing and external representation. They treat the organizational boundaries as defined with clear organizational structure, while consider that the boundary spanning activities need attention and examination given the amount of information the organization receives from the external environment. This function of information processing serves the organizational decision making process and therefore the role of boundary spanning is intra-organizational. Another function Aldrich and Herker (1977) investigate is representing the organization externally in the business environment and the role of boundary spanners is inter-organizational or inter-partner.

Similarly, Tushman.and Scanlan (1981) examined the organizational processes of information gathering and dissemination by boundary spanners. While Aldrich and Herker (1977) are reluctant to use the term boundary spanner Tushman.and Scanlan (1981) specify the functions of boundary spanning activities and the roles of boundary spanners. They also focus on informational roles played by boundary spanners in acquiring information from external sources and disseminate the information within the organization. Further, a new finding from their research is the two-step process of information flow where boundary spanners need perform not only information gathering from external sources but also information dissemination within the organization.

Friedman and Podolny (1992) studied the brokerage roles of inter-group boundary spanners. They posit that the exchange relationship that boundary spanners are responsible for contains 'a bundle 
of “flow”, such as advice, information, and trust' (Friedman \& Podolny, 1992: 29). In defining the role of boundary spanners they differentiate the content of the relational flows from the structure of mediation ties. There are two kinds of asymmetric mediation structures: one is called gatekeeper who is responsible for content inflows into the group, and the other is called representative who manages to communicate the content outflows to people outside the group.

In examining the potential tension between the scientific community and the business community (guild) within knowledge-intensive firms Mudambi and Swift (2009) posit that by linking the structural holes in the social network, building trust and lowering knowledge appropriability boundary spanners can effectively mitigate and leverage tensions between groups and units within organizations to achieve superior performance. McEvily, Perrone and Zaheer (2003) argue that specialized roles such as boundary spanners can be designated as 'a bridge' for effective management of interpersonal, inter-unit and inter-organizational relationships based on mutual trust.

\section{Conflicts and trust}

It is well documented that tensions and conflicts are elements of organizational life (Amason \& Schweiger, 1994; Boulding, 1963; Jehn \& Mannix, 2001; Mudambi and Swift, 2009; Schotter and Beamish, 2011). Boulding (1962) defines conflict as the awareness of the parties involved regarding discrepancies, goal incompatibility, or irreconcilable desires. Schotter and Beamish (2011) add to the list interest divergence and information asymmetry between actors. There are two types of conflict: one is cognitive and functional and the other affective and dysfunctional (Amason, 1996; Amason \& Schweiger, 1994). Cognitive conflict is focused on judgmental differences about how best to achieve common objectives. This type of conflict is also called task 
conflict (Jehn \& Mannix, 2001). Affective conflict is focused on personal incompatibilities or disputes. This type of conflict is also called relationship conflict (Jehn \& Mannix, 2001).

The majority of international business researchers, arguably with the exception of Schotter and Beamish (2011), treat conflict as a unitary construct in their research, resulting in a dichotomy between success and failure in outcomes and performance (Barner-Rasmussen et al., 2014; Kostova \& Roth, 2003; Mudambi \& Swift, 2009; Zaheer et al., 1998). It can be argued that cognitive conflict may not necessarily result in deteriorated relationships and failed outcomes. On the contrary, recurrence of cognitive conflicts may provide opportunities for parties involved to increase interaction frequency and establish trust relationship because cognitive conflict can enhance understanding between the partners and help increase commitment (Amason, 1996). It is the affective conflict that needs attention and mitigating. Therefore effectively managing and mitigating effective conflicts through trust building needs further investigation. And it is to the concept of trust we now turn.

\section{TRUST IN MNCS}

\section{Definition of trust}

Rousseau, Sitkin, Burt and Camerer (1998: 395) define trust as “a psychological state comprising the intention to accept vulnerability based upon positive expectations of the intentions or behavior of another”. In social exchange relationships interpersonal trust is underpinned by the principles of reliability and reciprocity (Blau, 1964). It means that one party's acceptance of vulnerability and the expectation that the other will perform a particular action irrespective of control or monitoring possibility (Mayer, Davis \& Schoorman, 1995; Das \& Teng, 1998). 
According to Deutsch (1960), trust refers to the personality characteristics that make a person 'trusting' and 'trustworthy'. The intension of the partners for cooperation requires 'mutual trust' (Deutsch, 1960: 124). Situational to the behaviour of the individual (trustor) in relation to the behaviour of another person (trustee) are uncertain path, perceived outcome, and confidence in trusting choice. In other words, an individual's choice of action for cooperation is contingent on the assumption that she/he is confident that the outcome of cooperation with another person will reduce costs and improve benefits, despite that the potential risk may arise along the path of cooperation. The social aspect of trust is well captured by Granovetter and he (1985: 489, italic original) notes that in spite of some economists' recognition that 'some degree of trust must be assumed to operate' because institutional arrangements could not simply guard against force or fraud, the source of this trust is left unexplored. Granovetter (1985: 491) goes on to argue that it is 'social relations, rather than institutional arrangements or generalized morality' that 'are mainly responsible for the production of trust in economic life'.

\section{Dimensions of trust}

Trust can be multidimensional depending on the researchers’ perspective. McAllister (1995: 25) identified two forms of interpersonal trust: (1) cognition-based trust which is based on individual beliefs about another person's reliability; and (2) affect-based trust that is grounded in reciprocity of the other party's care and concern. Whereas cognition-based trust requires control-based monitoring and develops defensive behaviour, affect-based trust requires need-based monitoring and develops citizenship behaviour. With affect-based trust he found that increasing interaction frequency is particularly effective. 
Madhok (1995) differentiated trust in two dimensions. In line with ownership structure the structural dimension of trust (structural trust) refers to the 'complementarity of the resources contributed' (1995: 120) by the IJV partners with complementarity of assets providing value-added for both partners. In contrast the social dimension of trust (social trust) indicates the quality of the relationship between IJV partners. Social trust is embedded in relational actions and interactions involving social and cognitive processes ((Kostova \& Roth, 2003; Salk \& Shenkar, 2001).

\section{Levels of trust}

The foregoing discussion of the definition and dimension of trust indicates that the concept of trust has its root at individual level. Zaheer, McEvily and Perrone (1998) contend that trust has its basis in individuals. Dyer and Chu (2011:11) argue that trust is fundamentally a construct delineating interpersonal relationships since “organizations cannot trust each other”. However, they recognize that interpersonal trust can manifest itself in collectives such as an organization through the process of institutionalization (Dyer \& Chu, 2011; Zaheer et al., 1998). It can be argued that the inception of trust relationship is between individuals. In organizational life individuals interact collectively in groups, units, and networks providing opportunities for individual-based trust relationship to spread intra-organization and inter-organization. As a result trust can be viewed a multilevel construct including interpersonal level, inter-group level, inter-unit level, and inter-organizational level. 


\section{Micro-macro process of trust-based boundary spanning}

It is intriguing that scholars take a process approach to research of boundary spanning and trust building (Aldrich \& Herker, 1977; Friedman \& Podolny, 1992; Kostova \& Roth, 2003; McEvily et al., 2003; Tushman.\& Scanlan, 1981; Zaheer et al., 1998) because both boundary spanning and trust building carry a temporal dimension. Many functions and activities of boundary spanning and trust building involve, among others, information processing, conflict mitigation, and social interaction. In addition, both boundary spanning and trust building in MNCs have a spatial property that moves between organizational levels and national borders. Therefore, a micro-macro process of boundary spanning and trust building is endogenously dynamic. Insights from this stream of research help us to develop a micro-macro process model of boundary spanning and trust building in IJVs in the following section. We propose a set of propositions to delineate our theoretical development.

\section{BOUNDARY SPANNERS AND TRUST BUILDING IN IJVS}

\section{The context of IJVs}

International joint ventures are legally independent entities established by two or more so-called parent companies from different countries, of which at least one parent is from outside the joint venture's country of operation (Chen et al., 2009; Geringer \& Hebert, 1989). The basis of most IJV structures involves an MNC and a local partner pooling their respective, dissimilar assets including intangible assets of knowledge and skills. 
Establishing IJVs causes structural changes within the MNC that make the MNC structurally more complex and geographically more dispersed. In light of such structural changes the tensions and conflicts within MNCs are elements of organizational life (Amason \& Schweiger, 1994; Mudambi and Swift, 2009; Schotter and Beamish, 2011). MNCs face the challenges of discerning blurred organizational boundaries, reconfiguring the existing control mechanisms, integrating diversified resources, and coordinating distributed subunit activities in time and space (Choi \& Beamish, 2004; Kostova \& Roth, 2003; Krishnan, Martin \& Noorderhaven, 2006; Parkhe, 1991). This is particularly so for IJVs since there are divergent underlying strategic motives amongst the partners. From MNC headquarters' perspective, ensuring that subunits' activities and performance are aligned with their own goals and objectives is critical yet problematic (Chen et al., 2010; Chen et al., 2009; Fryxell et al., 2002; Parkhe, 1991).

\section{Establishing structural trust in IJVs}

For the survival and development of IJVs partners' resource complementarity is vital for cooperation and this resource complementarity forms the basis of structural trust (Madhok, 1995). In concluding an agreement of the IJV ownership, defining subunit boundaries, and devising management control mechanisms, structural trust is being established and in principle providing value-added for both partners and contributing to the relationship that abstains from behaving in a self-interested manner. Nonetheless, Hambrick, Li, Xin and Tsui (2001: 1038) note that there is an inherent tendency of managers from the different IJV partners towards being 'competitive, turfconscious and rigid' which give rise to potential inter-partner tensions and conflicts. While structural trust is necessary for initial commitment to the IJV it is insufficient for the IJV partners to contribute to a long-term relationship ‘since contributions become much more tentative...[and] 
the cost of the operation increases since the greater expectation of opportunism by a partner causes the other to bear higher costs of installing safeguards against opportunism’ (Madhok, 1995: 121). Aulakh, Kotabe and Sahay (1996) argue that the mode of ownership control is an ex ante structuring condition for cross-border cooperation. Previous research findings show that there is a positive correlation between the need for control and the level of information flow (Madhok, 1995; Ring \& Van de Ven, 1992). At this stage IJV partners do not necessarily reach agreements on all the goals and objectives due largely to information asymmetry and potential agendas of selfinterest (Das \& Teng, 1998; Schotter \& Beamish, 2011).

Proposition 1: Inherent in the establishment of the IJV with perceived ex anti structural trust are potential latent inter-unit conflicts; the higher the level of information asymmetry the higher the propensity of inter-unit conflict.

------Insert Figure 1 about here------

In the early phase of the IJV after its establishment inter-unit information flows and representation primarily take place between the respective managers and key group leaders from the IJV partners. As a result, any potential conflicts at the inter-unit level will be translated into interpersonal level, the first dynamic change of the level of relationship. Our preceding discussion of the concept of conflict indicates that two types of interpersonal conflicts can exist in the IJV, namely functional cognitive conflict and dysfunctional affective conflict (Amason, 1996; Amason \& Schweiger, 1994). Despite the fact that the nature and properties of a potential inter-unit conflict are seemingly the same at a point in time, the outcomes of the conflict can be different contingent on the presence 
or absence of effective boundary spanners (Schotter \& Beamish, 2011). Not all members from the respective partner units working at the subunit boundaries can be regarded as boundary spanners because there is a difference between 'boundary spanning individuals and those who simply have substantial boundary spanning activity’ (Tushman.\& Scanlan, 1981: 84). The differentiation character between the two is whereas members with substantial boundary spanning activities are engaged in unidirectional activities such as internal information processing or external representation, effective boundary spanners are able to carry out both external representation and internal information processing and dissemination. Effective boundary spanners are task oriented with a focus on judgemental differences and their presence at the inter-unit boundaries help mitigate the level of inter-unit conflicts and any associated risks leading to functional interpersonal cognitive conflicts. Further, at the time of IJV formation the formal role of boundary spanners is not discussed and recognized as part of ownership and control systems since boundary spanning activities are not considered as a formal job (Schotter \& Beamish, 2011). As aforementioned there is a difference between a specified job and an unspecified role where a job is formal and organizationally defined and a role is emergent and socially defined, as part of a person's work experience (Perrone, Zaheer \& McEvily, 2003).

Proposition 2: In the presence of boundary spanners with unspecified roles the potential inter-unit conflict in the IJV is likely to be mitigated and positively translated into functional interpersonal cognitive conflict.

In contrast, in the absence of boundary spanners members of the respective subunits who have substantial boundary spanning activities may encounter emotional disputes due to personal 
incompatibilities. As a result the absence of boundary spanners will negatively translate the potential inter-unit conflicts into dysfunctional interpersonal affective conflicts.

Proposition 3: In the absence of boundary spanners the potential inter-unit conflicts in the IJV are likely to be negatively translated into dysfunctional interpersonal affective conflicts.

\section{Conflicts and trust at interpersonal level}

As elaborated above boundary spanners are task oriented with a focus on judgemental differences and their presence at the inter-unit boundaries leads potential inter-unit conflicts to become functional interpersonal cognitive conflicts. Schotter and Beamish (2011) found that cognitive conflict can generate positive outcomes. We contend that the positive correlation between cognitive conflict and performance outcomes is questionable and needs further examination. There is little doubt that cognitive conflict can enhance understanding between the partners and help increase commitment (Amason, 1996). However, it is trust rather than conflict that renders positive outcomes. Single occurrence of cognitive conflict is less likely to generate sustained relationship based on trust. Recurrence of cognitive conflicts may provide opportunities for parties involved to increase interaction frequency and establish trust relationship.

Proposition 4: Recurrence of interpersonal cognitive conflicts is positively related to building interpersonal trust between subunit boundary spanners of the IJV.

On the other hand, affective conflict can become emotional with a focus on personal incompatibilities or disputes (Amason, 1996). Affective conflict can cause personal feeling of frustration and dislike amongst subunit members (Jehn \& Mannix, 2001) which has detrimental 
effects to partner relationship (Schotter \& Beamish, 2011) and negative impact on interpersonal trust building. As it happens between members of the subunits working at the unit boundaries not only is it desirable but imperative that the headquarters attend to the situation and facilitate the training of boundary spanners to prevent similar incidents from happening. This is based on an assumption that the headquarters have the resources of capable boundary spanners.

Proposition 5: Interpersonal affective conflict is negatively related to building interpersonal trust between subunits of the IJV.

Proposition 5a: When the incident of interpersonal affective conflict occurs it requires headquarters intervention to identify boundary spanners and specify boundary spanning roles; the less frequent the occurrence of interpersonal cognitive conflict the more likelihood the building of interpersonal trust.

\section{Subunit boundary spanners building interpersonal trust}

If MNCs cannot rely on control mechanisms and ex ante structural trust to mitigate potential conflicts, especially the kind of affective conflicts, reduce risk, discourage opportunistic behavior inherent in IJVs, it is imperative that they adopt a trust-based social process to resolve conflicts and improve inter-partner cooperation as social trust is significantly more critical for IJV performance (Madhok, 1995). Social trust engenders a willingness by partners to endure hard relationship and conflicts and facilitate more efficient decision making by simplifying the acquisition and interpretation of information (McEvily et al., 2003). The social process of trust building mitigates the information asymmetries inherent in partner exchange relationship in the IJV by allowing more open and honest sharing of information (Zaheer et al., 1998). It is understood that by the time of building interpersonal trust both emergent boundary spanners through the path 
of interpersonal cognitive conflicts and trained boundary spanners through the path of interpersonal affective conflicts are present. Subunit boundary spanners are prepared to build interpersonal trust. Yet, there appear to be two resultant outcomes: one is affect-based trust and the other cognition-based trust. Affect-based trust is grounded in reciprocity of care and concern shown by the boundary spanners from the subunits of the IJV. Cognition-based trust, in contrast, is based on a subunit's boundary spanners' beliefs about another subunit's boundary spanners' reliability. This kind of trust requires information monitoring against opportunism. There is little doubt that affect-based interpersonal trust is an outcome more desirable than cognition-based interpersonal trust. Research shows that interpersonal interaction frequency is positively related to affect-based trust. (Kostova \& Roth, 2003; McAllister, 1995) and affect-based trust is likely to enhance information processing capabilities (Dooley \& Fryxell, 1999).

However, one should not expect that information asymmetry can be fully eliminated. Wherever information asymmetry exists between the subunits' boundary spanners one member is prone to be vulnerable and therefore attempts to monitor the other (Das \& Teng, 1998). The monitoring is most effective when the headquarters provide opportunities for the boundary spanners from the subunits to interact socially. In so doing cognition-based interpersonal trust can also contribute to affect-based interpersonal trust.

Proposition 6: Social process of interpersonal trust building between subunit boundary spanners will result in affect-based interpersonal trust amongst subunit boundary spanners in the IJV. 
Proposition 6a: The higher the frequency of interaction between subunit boundary spanners the higher the level of affect-based interpersonal trust.

Proposition 7: Informational process of interpersonal trust building between subunit boundary spanners will result in cognition-based interpersonal trust amongst subunit boundary spanners in the IJV; to be effective the process requires headquarters provision of social interaction between the subunit boundary spanners.

Proposition 8: Headquarters provision of opportunities of social interaction between subunit boundary spanners helps reduce the level of information asymmetry amongst subunit boundary spanners which in turn will contribute to affect-based interpersonal trust at the subunit level in the IJV.

\section{Institutionalizing interpersonal trust}

We have elaborated that trust is fundamentally a construct delineating interpersonal relationships (Dyer \& Chu, 2011; Zaheer et al., 1998). At the same time we recognize that interpersonal trust can manifest itself in groups, subunits, IJVs and MNCs through the process of institutionalization. When interpersonal trust, especially the kind of affect-based interpersonal trust, is built amongst boundary spanners at the subunit level, it is theoretically possible that dissemination of this kind of trust-based cooperative relationship can be anticipated and accepted by a greater number of subunit managers and employees alike. We have shown in our foregoing propositions that headquarters contribution to training subunit boundary spanners and reducing information asymmetry amongst subunit members is critical in the process of boundary spanning and trust building. In a similar vein, headquarters can contribute to the process of institutionalizing interpersonal trust at the subunit level. By institutionalizing interpersonal trust at the subunit level 
we observe the second dynamic change of the level of relationship. And increasing numbers of effective boundary spanners help accelerate the process of institutionalization of trust at various levels of the IJV. Ultimately, institutionalized interpersonal trust at the subunit level will generate a strong cooperative partnership and superior outcomes.

Proposition 9: Affect-based interpersonal trust between subunit boundary spanners are positively and strongly correlated to institutionalizing interpersonal trust into inter-unit trust in the IJV.

Proposition 9a: The greater the number of boundary spanners working at the subunit boundaries the higher the level of inter-unit trust in the IJV.

Proposition 10: Cognition-based interpersonal trust is positively but weakly correlated to inter-unit trust contingent on an appropriate level of headquarters intervention.

Proposition 10a: The greater the number of boundary spanners in the headquarters the higher the level of inter-unit trust in the IJV.

Proposition 11: Institutionalized inter-unit trust in the IJV will result in a strong cooperative partnership and superior outcomes.

\section{DISCUSSION AND CONCLUSION}

In the commentary of his Decade Award Article Madhok (2006: 4) made a strong appeal that 'more cross-disciplinary work to further our insights into the functioning of important phenomena of interest such as international joint ventures' in which trust plays a critical role.

During the last two decades a number of international business scholars have examined the role of trust plays in cross-border partnerships (Das \& Teng, 1998; Fryxell et al., 2002; Robson et al., 
2008; Zaheer et al., 1998). In spite of conflicting findings offered by different research work, a clear thread emerges from a stream of research, that is the attention paid to the role of boundary spanners and boundary spanning activities at various organizational levels of the MNCs (BarnerRasmussen et al., 2014; Koveshnikov et al., 2012; Kostova \& Roth, 2003; Mudambi \& Swift, 2009; Perrone,et al., 2003; Schotter \& Beamish, 2011; Zaheer et al., 1998). It can be argued that the introduction of the role of boundary spanning in building and maintaining trust relationship in the MNC is due largely to the functions of boundary spanning in reducing information asymmetry and resolving conflicts (Das \& Teng, 1998; Schotter \& Beamish, 2011).

A smaller number of scholars have taken a process approach to the research of boundary spanning and trust building in MNCs (Kostova and Roth, 2003; Schotter \& Beamish, 2011; Zaheer et al., 1998). But the focus of their research is primarily on the hierarchical relationship between the headquarters and subunits. Few, with the exception of Tallman and Chacar (2011), has paid attention to the networked relationship amongst MNC subunits. In this paper we attempt to fill this research gap by developing a dynamic micro-macro process model of boundary spanning and trust building in IJVs. We contribute to the literature and theory by elaborating the key concepts of boundary spanning, trust, conflict, and integrating them in a multi-level multi-process model which we believe will shed light on our current debate on the interactive effect of control mechanism, conflict mitigation, trust building and IJV performance outcomes.

Our proposed micro-macro process model incorporates both temporal and spatial dimensions and is endogenously dynamic. The structural, social, cognitive and relational components of the key concepts have been explicated and integrated. However, this paper has a number of limitations. 
First, we have primarily focused on the roles and functions of boundary spanner but ignored the issue of boundary setting. Second, the setting of our discussion and theoretical development of boundary spanning and trust building is the subunits of IJVs, generalization of our findings may be constrained. Finally, we have excluded the discussion of external context and its influence on boundary spanning and trust building. In this regard, more recent research by Zaheer and Kamal (2011) and Ertug, Cuypers, Noorderhaven and Bensaou (2013) will enhance our understanding of the effects country environments and cultural distances may have on the process of boundary spanning and trust building. 


\section{References}

Aldrich, H. \& Herker, D. (1977). Boundary Spanning Roles and Organization Structure. Academy of Management Review, 2, 217-230.

Amason, A. (1996). Distinguishing the Effects of Functional and Dysfunctional Conflict on Strategic Decision Making: Resolving a Paradox for Top Management Teams. Academy of Management Journal, 39, 123-148.

Amason, A. \& Schweiger, D. (1994). Resolving the paradox of conflict, strategic decision making and organizational performance. International Journal of Conflict Management, 5, 239253.

Ancona, D. \& Caldwell, D. (1992). Bridging the Boundary: External Activity and Performance in Organizational Teams. Administrative Science Quarterly, 37, 634-665.

Aulakh, P., Kotabe, M. \& Sahay, A. (1996). Trust and performance in cross-border marketing partnerships: A behavioral approach. Journal of International Business Studies, 27(5), 10051032.

Bamford, J., Ernst, D. \& Gubini, D. (2004). Launching a world-class joint venture, Harvard Business Review, 82(2), 91-100.

Barner-Rasmussen, W., Ehrnrooth, M., Koveshnikov, A \& Mäkelä, K. (2014). Cultural and language skills as resources for boundary spanning within the MNC. Journal of International Business Studies, 45, 886-905.

Bartlett, C. \& Ghoshal, S. (1989). Managing across borders; the transnational solution. Boston: Harvard Business School Press.

Blau, P. (1964). Exchange and Power in Social Life. New York: John Wiley.

Boulding, K. (1962). Conflict and Defense: A General Theory. New York: Harper \& Row.

Brouthers, K. \& Hennart, J. (2007). Boundaries of the Firm: Insights from International Entry Mode Research. Journal of Management, 33, 395-425.

Chen, D., Paik, Y. \& Park S. (2010). Host country policies and MNE management control in IJVs: Evidence from China. Journal of International Business Studies, 41, 526-537.

Chen, D., Park, S. \& Newburry, W. (2009). Parent contribution and organizational control in international joint ventures. Strategic Management Journal, 30, 1133-1156.

Choi, C. \& Beamish, P. (2004). Split management control and international joint venture performance. Journal of International Business Studies, 35, 201-215. 
Connelly, B., Miller, T. \& Devers, C. (2012). Under a cloud of suspicion: Trust and distrust, and their interactive effect in interorganizational contracting. Strategic Management Journal, 33, 820-833.

Currall, S. \& Inkpen, A. (2002). A multilevel approach to trust in joint ventures. Journal of International Business Studies, 33, 479-495.

Das, T. \& Teng, B. (1998). Between trust and control: Developing confidence in partner cooperation in alliances. Academy of Management Review, 23, 491-512.

Deutsch, M. (1960). The effect of motivational orientation upon trust and suspicion. Human Relations, 13, 123-139.

Doney, P., Cannon, J. \& Mullen, M. (1998). Understanding the Influence of National Culture on the Development of Trust. Academy of Management Review, 23, 601-620.

Dooley, D. \& Fryxell, G. (1999). Attaining decision quality and commitment from dissent: the moderating effects of competency and loyalty-based trust in strategic decision-making' Academy of Management Journal, 42, 389-402.

Dunning. J. ed. (2003) Making Globalization Good- The Moral Challenges of Global Capitalism. Oxford: Oxford University Press.

Dunning, J., Fujita, M. \& Yakova, N. (2007). Some macro-data on the regionalisation/globalisation debate: a comment on the Rugman/Verbeke analysis. Journal of International Business Studies, 38, 177-199.

Dyer, J. \& Chu, W. (2000). The determinants of trust in supplier-automaker relationships in the U.S., Japan and Korea. Journal of International Business Studies, 31, 259-285.

Dyer, J. \& Chu, W. (2011). The determinants of trust in supplier-automaker relationships in the U.S., Japan and Korea. Journal of International Business Studies, 42, 10-27.

Ertug, G., Cuypers, I., Noorderhaven, N. \& Bensaou, B. (2013). Trust between international joint venture partners: Effects of home countries. Journal of International Business Studies, 44, 263282.

Felin, T., Foss,N. J., Heimericks, K. H., \& Madsen, T. L. (2012). Microfoundations of routines and capabilities: Individuals, processes and structure. Journal of Management Studies, 49, 13511374.

Forsgren, M. Holm, U. \& Johanson, J. (2006). Managing the Embedded Multinational: A Business Network View. Cheltenham: Edward Elgar.

Friedman, R. \& Podolny, J. (1992). Differentiation of Boundary Spanning Roles: Labor Negotiations and Implications for Role Conflict. Administrative Science Quarterly, 37, 28-47. 
Fryxell, G., Dooley, R. \& Vryza, M. (2002). After the ink dries: The interaction of trust and control in US-based international joint ventures. Journal of Management Studies, 39, 865-886.

Ghemawat, P. (2005). Regional strategies for global leadership. Harvard Business Review, 83(12), 98-108.

Geringer , M. \& Hebert, L. (1991). Measuring performance in international joint ventures. Journal of International Business Studies, 22, 249-263.

Geringer , M. \& Hebert, L. (1989). Control and performance of international joint ventures. Journal of International Business Studies, 20, 235-54.

Granovetter, M. (1985). Economic action and social structure: A theory of embeddedness. American Journal of Sociology, 91, 481-510.

Gulati, R. (1995). Does familiarity breed trust? The implications of repeated ties for contractual choice in alliances. Academy of Management Journal, 38, 85-112.

Hambrick, D., Li, J., Xin, K. \& Tsui, A. (2001). Compositional gaps and downward spirals in international joint venture management groups. Strategic Management Journal, 22(11), 10331053.

Hitt, M., Dacin, M., Levitas, E., Arregle, J. \& Borza, A. (2000). Partner selection in emerging and developed market contexts: resource-based and organizational learning perspectives. Academy of Management Journal, 43, 449-467.

Inkpen, A. \& Beamish, P. (1997). Knowledge, bargaining power, and the instability of international joint ventures. Academy of Management Review, 22, 177-202.

Jehn, K. \& Mannix, E. (2001). The Dynamic Nature of Conflict: A Longitudinal Study of Intragroup Conflict and Group Performance. Academy of Management Journal, 44, 238-251.

Katz, D. \& R. Kahn (1978). The Social Psychology of Organizations. New York: Wiley.

Kostova, T. \& Roth, K. (2003). Social capital in multinational corporations and a micro-macro model of its formation. Academy of Management Review, 28, 297-317.

Koveshnikov, A., Barner-Rasmussen, W., Ehrnrooth, M., \& Mäkelä, K. (2012). A framework of successful organizational practices in Western multinational companies operating in Russia. Journal of World Business, 47, 371-382.

Krishnan, R., Martin, X., \& Noorderhaven, N. (2006). When does trust matter to alliance performance? Academy of Management Journal, 49, 894-917.

Li, J., Poppo, L. \& Zhou, K. (2010). Relational mechanisms, formal contracts, and local knowledge acquisition by international subsidiaries. Strategic Management Journal, 31, 349370. 
Luo, Y. (2007). Are joint venture partners more opportunistic in a more volatile environment? Strategic Management Journal. 28, 39-61.

Madhok, A. (1995). Revisiting multinational firms' tolerance for joint ventures: a trust-based approach. Journal of International Business Studies, 26, 117-137.

Madhok, A. (2006). How much does ownership really matter? Equity and trust relations in joint venture relationships. Journal of International Business Studies, 37, 4-11.

McAllister, D. (1995). Affect- and Cognition-Based Trust as Foundations for Interpersonal Cooperation in Organizations. Academy of Management Journal, 38, 24-59.

Mayer, R., Davis, J. \& Schoorman, D. (1995). An integrative model of organizational trust. Academy of Management Review, 20, 709-734.

McEvily, B., Perrone, V. \& Zaheer, A. (2003). Trust as an Organizing Principle. Organization Science, 14, 91-103.

Mudambi, R \& Swift, T. (2009). Professional guilds, tension and knowledge management. Research Policy, 38, 736-745.

Nooteboom, B., Berger, H. \& Noorderhaven, N. (1997). Effects of trust and governance on relational risk. Academy of Management Journal, 40, 308-338.

Parkhe, A. (1991). Interfirm diversity, organizational learning, and longevity in global strategic alliances. Journal of International Business Studies, 22, 579-601.

Parkhe, A. (1998). Building trust in international alliances. Journal of World Business, 33, 417437.

Perrone, V., Zaheer, A. \& McEvily. B. (2003). Free to Be Trusted? Organizational Constraints on Trust in Boundary Spanners. Organization Science, 14, 422-439.

Robson, M., Leonidou, L. \& Katsikeas, C. (2002). Factors influencing international joint venture performance: Theoretical perspectives, assessment and future directions. Management International Review, 42, 385-418.

Robson, M., Katsikeas, C. \& Bello, D. (2008). Drivers and performance outcomes of trust in international strategic alliances: The role of organizational complexity. Organization Science, 19, 647-665.

Rousseau, D., Sitkin, S., Burt, R. \& Camerer, C. (1998). Not so different after all: A crossdiscipline view of trust. Academy of Management Review, 23, 393-404.

Rugman, A. \& Verbeke, A. (2004). A perspective on regional and global strategies of multinational enterprises. Journal of International Business Studies, 35, 3-18. 
Rugman, A. \& Verbeke, A. (2007). Liabilities of regional foreignness and the use of firm-level versus country-level data: A response to Dunning et al. (2007). Journal of International

Business Studies, 38, 200-205.

Salk, J. \& Shenkar, O. (2001). Social identities in an international joint venture: An exploratory case study. Organizational Science, 12, 161-178.

Schotter, A. \& Beamish, P.W. (2011). Performance effects of MNC headquarters-subsidiary conflict and the role of boundary spanners: The case of headquarter initiative rejection. Journal of International Management, 17, 243-259.

Silva, S., Bradley, F. \& Sousa, C. (2012). Empirical test of the trust - performance link in an international alliances context. International Business Review 21, 293-306.

Steensma, H. \& Lyles, M. (2000). Explaining IJV survival in a transitional economy through social exchange and knowledge-based perspectives. Strategic Management Journal. 21, 831851.

Tallman, S. \& Chacar, A. (2011). Communities, alliances, networks and knowledge in multinational firms: A micro-analytic framework. Journal of International Management, 17, 201-210.

Thompson, J. (1967). Organizations in action. New York: McGraw-Hill.

Tushman, M. (1977). Special Boundary Roles in the Innovation Process. Administrative Science Quarterly, 22, 587-605.

Tushman, M. \& Scanlan, T. (1981). Boundary Spanning Individuals: Their Role in Information Transfer and Their Antecedents. Academy of Management Journal, 24, 289-305.

Williamson, O. (1993). Calculativeness, trust, and economic organization. Journal of Law \& Economics, 36, 453-486.

Yip, G. (1992). Total Global Strategy: Managing for Worldwide Competitive Advantage. Englewood Cliffs, NJ: Prentice-Hall.

Zaheer, A. \& Kamal, D. (2011). Creating trust in piranha-infested waters: The confluence of buyer, supplier and host country contexts. Journal of International Business Studies, 42, 48-55.

Zaheer, A., McEvily, B. \& Perrone, V. (1998). Does trust matter? Exploring the effects of interorganizational and interpersonal trust on performance. Organization Science, 9, 141-159. 
Figure 1. Dynamic process of boundary spanning and trust building in IJVs

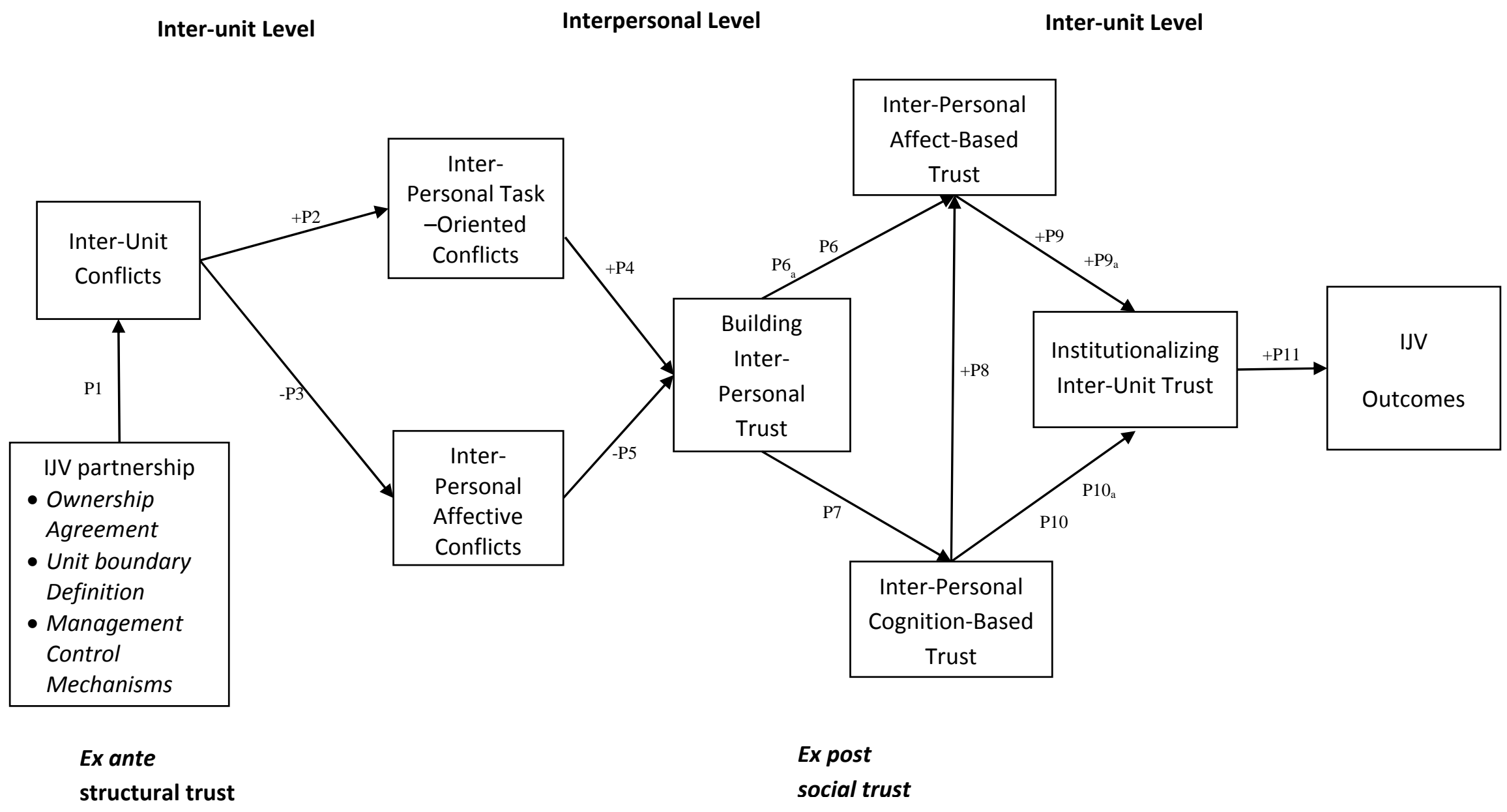

